JAMP: Jurnal Adminitrasi dan Manajemen Pendidikan

Volume 3 Nomor 3 September 2020, Hal : 249-261

Tersedia Online di http://journal2.um.ac.id/index.php/jamp/

ISSN 2615-8574 (online)

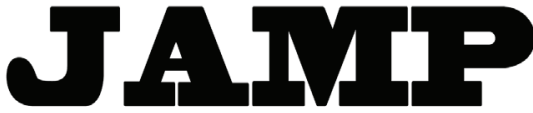

JURNAL ADMINISTRASI DAN MANAJEMEN PENDIDIKAN

\title{
STRATEGI PEMASARAN JASA PENDIDIKAN DALAM MENARIK MINAT MASYARAKAT MELALUI PROGRAM KELAS KHUSUS
}

\author{
Frizkania Lutfi Annisa Fira \\ Nurul Ulfatin \\ Djum Djum Noor Benty \\ Universitas Negeri Malang \\ J1. Semarang, No. 5 Malang \\ Email: Anisafira098@gmail.com
}

\begin{abstract}
This study aims to describe the Service Marketing Strategy in Attracting Public Interest through the Special Class Program. This research uses a qualitative method with the type of case study. Research data collection by interview, observation, and study documentation. The findings of this study include special classes, strategies, planning, implementation, evaluation, constraints, solutions, supporting factors, and optimizing supporting factors in the education services marketing strategy that is used to attract public interest through special class programs.
\end{abstract}

Keywords: marketing education services, community interests, special classes

\begin{abstract}
Abstrak: Penelitian ini bertujuan untuk mendeskripsikan mengenai Strategi Pemasaran Jasa dalam Menarik Minat Masyarakat melalui Program Kelas Khusus. Penelitian ini menggunakan metode kualitatif dengan jenis studi kasus. Pengumpulan data penelitian dengan wawancara, observasi, dan studi dokumentasi. Hasil temuan penelitian ini mencakup kelas khusus, strategi, perencanaan, implementasi, evaluasi, kendala, solusi, faktor pendukung, dan pengoptimalan faktor pendukung dalam strategi pemasaran jasa pendidikan yang digunakan untuk menarik minat masyarakat melalui program kelas khusus.
\end{abstract}

Kata Kunci: pemasaran jasa pendidikan, minat masyarakat, kelas khusus

Lembaga pendidikan sangat dibutuhkan oleh masyarakat untuk meningkatkan kemampuan yang dimiliki. Saat ini banyak lembaga pendidikan yang ada di masyarakat, jika lembaga pendidikan ingin dikenal dan diingat oleh masyarakat tentunya harus mempunyai strategi pemasaran yang dapat menarik minat agar masyarakat lebih mengenal dan tertarik pada lembaga pendidikan tersebut. Persaingan lembaga pendidikan sangatlah ketat, maka dari itu lembaga pendidikan harus mempunyai strategi-strategi khusus dalam memasarkan jasa pendidikan yang dimiliki untuk menarik minat masyarakat. Dalam kegiatan pemasaran sekolah harus selalu melakukan kerjasama dan menjalin hubungan baik dengan masyarakat. Pemasaran jasa merupakan cara untuk mencari konsumen agar tertarik dengan lembaga pendidikan tertentu. Seperti yang dijelaskan dalam Benty dan Gunawan (2015:20) menyebutkan bahwa konsumen merupakan fokus dari kegiatan pemasaran, jika membahas mengenai kegiatan pemasaran berarti membahas mengenai bagaimana kiat untuk memuaskan konsumen.

Maraknya sekolah yang ada saat ini, tidak hanya sekolah negeri milik pemerintah saja namun ada sekolah swasta yang jumlahnya juga semakin banyak. Sistem yang digunakan sekolah negeri saat ini yaitu sistem zonasi untuk kegiatan penerimaan siswa baru, namun untuk sekolah swasta harus berusaha menarik sendiri minat masyarakat agar mau bersekolah di sekolah ini. Maka dari itu, sekolah swasta 
harus memiliki strategi dalam kegiatan pemasaran jasa pendidikan yang dimiliki dengan melakukan promosi mengenai keunggulan serta bukti-bukti nyata agar masyarakat percaya terhadap sekolah. Selain untuk mencari calon peserta didik pemasaran jasa yang dilakukan di sekolah tentunya berguna untuk menjalin hubungan yang baik dengan para wali peserta didik agar senantiasa mendukung dan membantu kegiatan yang diadakan oleh sekolah.

Peneliti melakukan kegiatan observasi dibeberapa sekolah swasta yang ada di Kota Kediri, peneliti tertarik pada pemasaran yang dilakukan oleh MI Al-Irsyad Al-Islamiyyah melalui program kelas khusus. Pemasaran yang dilakukan yaitu melalui media sosial, media cetak, mulut ke mulut, dan programprogram unggulan seperti kelas khusus. Media sosial yang digunakan untuk kegiatan pemasaran jasa yaitu instagram, youtube, facebook, website, dan berita online. Selanjutnya, untuk media cetak yaitu brosur, banner, dan kalender. Untuk program-program yang diunggulkan dari sekolah ini yaitu program kelas khusus yang lebih menekankan kepada akademik siswa, pembelajaran Al-quran, dan akhlak. Pemasaran jasa pendidikan yang dilakukan oleh MI Al-Irsyad Al-Islamiyyah Kediri salah satunya yaitu program kelas khusus. Kelas khusus adalah kelas yang menyediakan program-program serta pelayanan yang lebih khusus dibandingkan dengan kelas reguler tentunya peserta didik yang dapat masuk ke dalam kelas khusus ini harus terseleksi terlebih dahulu. Pengelolaan kelas khusus ini sangat melibatkan peran orangtua, bahkan fasilitas-fasilitas tambahan serta perawatan fasilitas tersebut orangtua selalu berperan karena memang dalam program ini Kepala Madrasah lebih mengikut sertakan peran orangtua dalam pengembangan program ini atau bisa disebut peningkatan Peran Serta Masyarakat (PSM) agar hubungan baik antara sekolah dan masyarakat dapat berjalan dengan baik demi menunjang kegiatan pembelajaran di sekolah. Tambahan pembayaran ini dikarenakan fasilitas sarana dan prasarana yang lebih bagus, guruguru yang memiliki kemampuan yang bagus, serta tambahan jam pelajaran. Kegiatan pembelajaran di kelas khusus ini peserta didik mulai dari kelas dua sudah diajarkan materi-materi yang akan di gunakan untuk Ujian Nasional (UN) atau terdapat tambahan jam pelajaran untuk materi yang diujikan. Selain itu, kegiatan keagamaan yang lebih banyak seperti sholat dhuha hari senin-jumat, pembelajaran akidah akhlak, mengaji dan tahfidzul qur' an yang dilakukan mulai hari senin-kamis.

Berdasarkan uraian yang telah disebutkan diatas, maka peneliti akan melakukan penelitian serta mengkaji lebih dalam mengenai strategi pemasaran jasa pendidikan dalam menarik minat masyarakat melalui program kelas khusus yang bertempat di MI Al-Irsyad Al-Islamiyyah Kota Kediri. Tujuan penelitian ini adalah (1) mampu mendeskripsikan program kelas khusus; (2) dapat mendeskripsikan strategi pemasaran jasa pendidikan dalam menarik minat masyarakat melalui program kelas khusus; (3) mampu mendeskripsikan perencanaan strategi pemasaran jasa pendidikan dalam menarik minat masyarakat melalui program kelas khusus; (4) dapat mendeskripsikan implementasi strategi pemasaran jasa pendidikan dalam menarik minat masyarakat melalui program kelas khusus; (5) mampu mendeskripsikan evaluasi strategi pemasaran jasa pendidikan dalam menarik minat masyarakat melalui program kelas khusus; (6) dapat mendeskripsikan faktor kendala strategi pemasaran jasa pendidikan dalam menarik minat masyarakat melalui program kelas khusus; (7) mampu mendeskripsikan solusi yang dilakukan untuk mengatasi kendala yang dihadapi strategi pemasaran jasa pendidikan dalam menarik minat masyarakat melalui program kelas khusus; (8) dapat mendeskripsikan faktor pendukung strategi pemasaran jasa pendidikan dalam menarik minat masyarakat melalui program kelas khusus; (9) mampu mendeskripsikan upaya mengoptimalkan faktor pendukung strategi pemasaran jasa pendidikan dalam menarik minat masyarakat melalui program kelas khusus.

\section{METODE}

Penelitian ini menggunakan pendekatan kualitatif dengan bentuk studi kasus dikarenakan penelitian ini bertujuan untuk mengungkap, melakukan pemahaman, dan penggambaran suatu objek secara mendalam (Ulfatin, 2015). Penelitian ini mengenai strategi pemasaran jasa pendidikan dalam menarik minat masyarakat melalui program kelas khusus di MI Al Irsyad Al Islamiyyah Kota Kediri. Teknik yang digunakan dalam pengumpulan data penelitian ialah wawancara, observasi dan dokumentasi. Alasan peneliti memilih MI Al Irsyad Al Islamiyyah Kota Kediri sebagai tempat penelitian dikarenakan sekolah 
ini merupakan sekolah swasta yang sangat diminati oleh masyarakat dan sekolah ini melaksanakan program kelas khusus yang berbeda penerapannya dengan sekolah yang lainnya. Alasan ini merujuk Yin (2009) yang mengatakan bahwa studi kasus tepat digunakan jika peneliti ingin mendalami keunikan dari suatu objek penelitian.

Peneliti melakukan kegiatan wawancara secara mendalam untuk memperoleh informasi secara lengkap, narasumber dari kegiatan wawancara ini ialah Kepala Sekolah, Waka Kurikulum, Waka Kesiswaan, Waka Administrasi sekaligus kepala bagian kelas khusus, guru kelas khusus, dan wali murid yang secara keseluruhan berjumlah 10 orang partisipan. Selain itu, peneliti juga melakukan kegiatan observasi, dalam kegiatan ini peneliti melakukan interaksi dengan orang-orang yang dapat memberikan informasi mengenai bahan penelitian dan peneliti juga melakukan pengamatan terhadap kegiatan-kegiatan yang berkaitan dengan kelas khusus dan pemasaran yang dilakukan oleh sekolah. Teknik dokumentasi juga dilakukan oleh peneliti dalam pengumpulan data penelitian agar temuan serta informasi yang diperoleh dapat lebih jelas. Dokumentasi ini digunakan juga sebagai bukti untuk memperkuat hasil temuan pada wawancara dan observasi. Selanjutnya, peneliti melakukan analisis data secara interaktif dengan tahapan yaitu pengumpulan data, reduksi data, penyajian data dan menarik kesimpulan. Dalam pengecekan keabsahan data, peneliti menggunakan cara triangulasi, pengecekan anggota, meningkatkan ketekunan, dan kecukupan bahan referensi.

\section{HASIL}

\section{Program Kelas Khusus}

Temuan penelitian terkait dengan program kelas khusus di MI Al Irsyad Al Islamiyyah Kota Kediri, sebagaimana disajikan pada Tabel 1.

Tabel 1. Temuan Penelitian tentang Program Kelas Khusus

\begin{tabular}{|c|c|c|}
\hline No & Kelas Reguler & Kelas Khusus \\
\hline 1 & $\begin{array}{l}\text { Kurikulum yang digunakan yaitu kurikulum } \\
2013\end{array}$ & $\begin{array}{l}\text { Kurikulum yang digunakan yaitu } \\
\text { memaduka kurikulum } 2013 \text { dan } \\
\text { kurikulum yang dikembangkan oleh } \\
\text { sekolah. }\end{array}$ \\
\hline 2 & $\begin{array}{l}\text { Jam pulang: senin-kamis pukul } 14.00 \text {, jumat } \\
\text { pukul } 10.35 \text {, dan sabtu pukul } 11.00\end{array}$ & $\begin{array}{l}\text { Jam pulang: senin-kamis pukul } 16.00 \text {, } \\
\text { Jumat: } 15.00 \text { (jumatan di sekolah), dan } \\
\text { sabtu pukul } 11.00\end{array}$ \\
\hline 3 & $\begin{array}{l}\text { Pelajaran mengaji dan tahfidz dilakukan } \\
\text { seminggu sekali. }\end{array}$ & $\begin{array}{l}\text { Pelajaran mengaji dan tahfidz dilakukan } \\
\text { hampir setiap hari. }\end{array}$ \\
\hline 4 & Tidak terdapat pelajaran tambahan & $\begin{array}{l}\text { Terdapat pelajaran tambahan dalam } \\
\text { pelajaran IPA khusus, Matematika } \\
\text { khusus, dan Bahasa Indonesia Khusus }\end{array}$ \\
\hline 5 & $\begin{array}{l}\text { Pembelajaran untuk UN dilakukan mulai dari } \\
\text { Kelas } 5\end{array}$ & $\begin{array}{l}\text { Pembelajaran UN dimulai dari Kelas } 2 \\
\text { setelah masuk ke kelas khusus, materi- } \\
\text { materinya di sesuaikan dengan tingkatan. }\end{array}$ \\
\hline 6 & Fasilitas kelas sesuai dengan SNP & $\begin{array}{l}\text { Fasilitas kelas lebih dari SNP karena } \\
\text { fasilitas kelas dibiayai oleh wali murid } \\
\text { seperti adanya AC, LCD proyektor, } \\
\text { Android box, loker, dispenser dan lain- } \\
\text { lain. }\end{array}$ \\
\hline 7 & $\begin{array}{l}\text { Sholat yang dilakukan di sekolah yaitu sholat } \\
\text { dzuhur setiap hari senin-kamis dan sholat } \\
\text { dhuha yang dilakukan hari jumat. }\end{array}$ & $\begin{array}{l}\text { Sholat dzuhur dan ashar setiap hari } \\
\text { senin-kamis, sholat dhuha dilakukan } \\
\text { setiap senin-jumat, dan setiap jumat } \\
\text { peserta didik laki-laki melakukan sholat } \\
\text { jumat di sekolah dan untuk peserta didik } \\
\text { perempuan terdapat kegiatan keputrian } \\
\text { (pemberian informasi mengenai } \\
\text { perempuan) }\end{array}$ \\
\hline
\end{tabular}




\begin{tabular}{cll}
\hline No & \multicolumn{1}{c}{ Kelas Reguler } & \multicolumn{1}{c}{ Kelas Khusus } \\
\hline 8 & Kegiatan pembelajaran yang dilakukan yaitu & Kegiatan pembelajaran dimulai dengan \\
& BTQ dilanjut dengan pelajaran umumnya & kegiatan sholat dhuha, dilanjut dengan \\
& setelah itu pukul 09.50-10.25 istirahat dan & pelajaran sampai pukul 11.30 setelah \\
dilanjut dengan pelajaran sampai pukul & itu sholat dzuhur, istirahat makan, \\
12.50 setelah itu sholat dzuhur, setelah sholat & dan istirahat tidur (untuk kelas atas \\
& dilanjutkan 1 pelajaran umum sampai pukul & 30 menit dan kelas bawah 1 jam) lalu \\
14.00. Pada hari sabtu diisi dengan kegiatan & dilanjutkan pelajaran sampai pukul 14.00 \\
pramuka dan ekstrakurikuler. Lama jam & dan dilanjut dengan mengaji, setelah \\
pelajaran jika di reguler 35 menit per jam & mengaji dilakukan sholat ashar sampai \\
pelajaran. & pukul 15.30, setelah itu dilanjut dengan \\
& & tahfidzul qur'an. Untuk kegiatan hari \\
& & sabtu diisi dengan kegiatan pramuka \\
& & dilanjut dengan pelajaran 2 jam pelajaran \\
& & dan ekstrakurikuler. Lama jam pelajaran \\
& & di kelas khusus 30 menit per jam \\
& Try out dilakukan di Kelas 6 & pelajaran. \\
& & Try out dilakukan mulai dari Kelas 5 \\
& & yaitu dengan cara computer based test \\
& menggunakan smartphone di hari jumat
\end{tabular}

Berdasarkan penjelasan pada Tabel 1, terdapat beberapa hal mengenai alasan sekolah membuat kelas khusus ini yaitu: 1) pembuatan kelas khusus ini digunakan untuk mengumpulkan anak-anak yang memiliki prestasi tetapi tidak mengecilkan perasaan kelas reguler, 2) dapat membantu pembiayaan sekolah seperti dalam hal gaji dewan guru dan sarana dan prasarana maupun perawatannya yang ada di kelas khusus, 3) membuat program sekolah ditambah dengan bimbingan belajar serta mengaji sehingga mempermudah orangtua karena tidak perlu mencarikan hal tersebut, dan 4) mengikuti perkembangan zaman.

Setelah masuk ke kelas khusus ini, peningkatan kemampuan yang dimiliki peserta didik yaitu 1) jiwa kompetisi peserta didik lebih meningkat, dibuktikannya dengan terus berlomba-lomba untuk mendapatkan peringkat saat di kelas khusus, jadi tidak hanya beberapa anak saja yang menonjol tetapi hampir semua bersaing dalam hal tersebut, 2) peserta didik yang masuk ke kelas khusus ini merupakan peserta didik pilihan, jadi dengan lingkungan yang tingkat keseriusan belajar yang tinggi dapat memberikan dampak yang positif ke sesama, 3) waktu dan perhatian yang diberikan lebih banyak diberikan oleh guru kepada peserta didik sehingga memudahkan untuk mengontrol peserta didik, 4) adanya tambahan pelajaran yang diberikan kepada peserta didik sehingga mereka dibentuk untuk pribadi yang lebih kuat, dan 5) motivasi yang diberikan oleh guru secara rutin terus menerus seperti kegiatan video motivasi menjadikan banyak pelajaran yang diambil dari video dan semangat bagi peserta didik.

\section{Strategi Pemasaran Jasa Pendidikan dalam Menarik Minat Masyarakat melalui Program Kelas Khusus}

Hasil temuan peneliti mengenai strategi yang digunakan dalam pemasaran jasa pendidikan dalam menarik minat masyarakat pada program kelas khusus yang dilakukan MI Al-Irsyad Al-Islamiyyah Kota Kediri, terdapat berbagai strategi yang digunakan yaitu sebagai berikut: 1) mempromosikan kelas khusus kepada wali murid serta menjelaskan keunggulan-keunggulan kelas khusus yang menjadi pembeda kelas khusus dengan sekolah fullday yang lain yaitu selain memperhatikan PBM di kelas khusus ini juga memperhatikan istirahat dan makan peserta didik, 2) strategi selanjutnya yaitu menginformasikan secara nyata tanpa pencitraan mengenai kelas khusus ini, jadi wali murid atau masyarakat dapat melihat langsung secara nyata bagaimana program kelas khusus ini tanpa dibuat-buat, 3) selalu melakukan pembenahan mengenai manajemen, fasilitas kelas khusus, dan output yang dihasilkan, 4) mengundang wali murid untuk mengikuti beberapa kegiatan yang dilakukan oleh sekolah yang cocok untuk wali murid, dan 5) mempromosikan hasil-hasil yang diperoleh oleh kelas khusus bisa berupa kejuaraan dan 
hasil-hasil belajar lainnya bisa dalam bidang akademik maupun non akademik.

\section{Perencanaan Strategi Pemasaran Jasa Pendidikan dalam Menarik Minat Masyarakat melalui Program Kelas Khusus}

Hasil temuan penelitian mengenai tahapan perencanaan dalam penyusunan strategi yang dipilih sekolah ialah melakukan identifikasi mengenai kebutuhan sekolah, identifikasi ini bisa berupa kelemahan dan kelebihan yang dimiliki sekolah. Identifikasi ini dilakukan agar kegiatan-kegiatan yang dilakukan oleh sekolah sesuai dengan tujuan dari sekolah. Selanjutnya sekolah biasa mengadakan rapat untuk membahas mengenai perkembangan pendidikan secara nasional lalu mengidentifikasi perkembangan itu agar bisa diterapkan sesuai dengan keadaan sekolah. Selain itu, sekolah melakukan pertukaran informasi dari lembaga-lembaga lain untuk mendapatkan ilmu maupun informasi mengenai lembaga tersebut, lalu sekolah dapat melakukan inovasi terbaru dengan mendapatkan ilmu dari pihak-pihak lain tetapi tetap disesuaikan dengan keadaan sekolah. Tahap perencanaan ini sekolah juga melakukan penentuan target sasaran yang digunakan untuk pemasaran jasa pendidikan pada kelas khusus ini.

\section{Implementasi Strategi Pemasaran Jasa Pendidikan dalam Menarik Minat Masyarakat melalui Program Kelas Khusus}

Hasil temuan kegiatan implementasi strategi pemasaran jasa pendidikan dalam menarik minat masyarakat melalui program kelas khusus. Kegiatan-kegiatannya yaitu sebagai berikut: 1) sekolah mengikuti lomba-lomba yang diadakan oleh pihak luar untuk digunakan sebagai promosi dan jika memperoleh juara maka nama sekolah dan prestasi sekolah akan lebih dikenal oleh masyarakat secara luas, 2) hasil-hasil belajar siswa, seperti tryout ditempel agar bisa dilihat oleh wali murid atau masyarakat yang ingin masuk ke sekolah tersebut, 3) melakukan pembenahan dalam kegiatan yang kurang optimal pada tahun sebelumnya, seperti contohnya perawatan atau perbaikan sarana dan prasarana yang ada di sekolah, 4) melakukan promosi melalui brosur dan media sosial yang dimiliki oleh sekolah agar masyarakat mudah untuk melihat kegiatan-kegiatan yang dilakukan oleh sekolah serta mencari informasi,dan 5) sering melakukan sosialisasi dan diskusi dengan wali murid agar tidak terjadi selisih paham dan hubungan baik antara sekolah dan wali murid tetap terjalin dengan baik.

\section{Evaluasi Strategi Pemasaran Jasa Pendidikan dalam Menarik Minat Masyarakat melalui Program Kelas Khusus}

Setiap kegiatan tentunya memerlukan evaluasi untuk mengetahui ukuran serta penilaian mengenai kegiatan setelah kegiatan tersebut berjalan. Evaluasi ini bertujuan untuk melakukan penyesuaian serta perbaikan kegiatan-kegiatan yang dianggap kurang maksimal agar dapat berjalan sesuai dengan tujuan yang telah ditetapkan. Kegiatan evaluasi yang dilakukan sekolah ini dibagi menjadi 3 jenis yaitu evaluasi jangka panjang, jangka menengah, dan jangka pendek.

Acuan yang digunakan sekolah pada tahapan evaluasi yaitu sebagai berikut: 1) acuan yang dipertimbangkan oleh sekolah yaitu minat orangtua/keinginan terhadap sekolah, 2) ketersediaan sarana dan prasarana yang dimiliki oleh sekolah, 3) kurikulum yang digunakan di kelas khusus yaitu kurikulum 2013 dan kurikulum pengembangan dari sekolah, 4) visi, misi dan motto sekolah karena setiap sekolah tentunya memiliki visi,misi, dan tujuan tersendiri yang sesuai dengan keadaan sekolah, dan 5)Melihat perkembangan kegiatan yang telah dilakukan sebelumnya, karena dapat digunakan untuk mengidentifikasi hal-hal yang perlu dibenahi agar sesuai tujuan. Setelah melakukan kegiatan evaluasi dapat diketahui bahwa indikator keberhasilan pemasaran jasa pendidikan dalam menarik minat masyarakat melalui kelas khusus ini adalah keberhasilan sekolah untuk meningkatkan daya tarik masyarakat dalam program kelas khusus, terbukti dari meningkatnya jumlah peserta didik yang setiap tahun mengalami peningkatan dan untuk tahun ini bisa sampai overload.

\section{Faktor Kendala Strategi Pemasaran Jasa Pendidikan dalam Menarik Minat Masyarakat melalui Program Kelas Khusus}

Terdapat dua macam kendala yang dihadapi yaitu kendala yang berasal dari orangtua dan berasal dari sekolah. Kendala yang berasal dari orangtua meliputi: 1) wali murid yang memiliki ekspektasi yang 
tinggi, ditakutkan ekspektasi mereka tidak sesuai dengan apa yang diterapkan. Maka dari itu kendala muncul ketika keinginan wali murid dan sekolah mengalami perbedaan, dan 2) terdapat beberapa wali murid yang kurang memiliki komitmen, komitmen disini menyangkut masalah pembayaran karena di kelas khusus ini sedikit lebih banyak biaya dari pada kelas reguler. Jika pembiayaan mereka rendah tetapi tetap memaksakan untuk masuk maka akan mengganggu kelancaran program-program yang ada. Sedangkan kendala-kendala yang dialami berasal dari pihak sekolah sebagai berikut: 1) tidak semua guru yang dapat menjelaskan dan paham mengenai kelas khusus sehingga mengakibatkan perbedaan pemahaman, jadi ketika wali murid menanyakan ditakutkan berbeda penjelasan, dan 2) kesibukan masing-masing Ulul Albab sekolah sehingga sulit sekali mencari waktu yang tepat untuk melakukan pertemuan berdiskusi. Kesibukan disini dikarenakan para petinggi-petinggi sekolah memiliki tugas dan kegiatan tambahan di sekolah maupun di luar sekolah.

\section{Solusi Yang Dilakukan untuk Mengatasi Kendala yang Dihadapi Strategi Pemasaran Jasa Pendidikan dalam Menarik Minat Masyarakat melalui Program Kelas Khusus}

Kendala yang dihadapi berasal dari faktor orangtua dan sekolah, maka solusi yang digunakan juga digunakan untuk orangtua dan sekolah. solusi yang dipilih untuk mengatasi kendala yang berasal dari orangtua yaitu: 1) untuk mengatasi masalah pembiayaan, yang pertama dilakukan dengan komunikasi dan solusi dengan paguyuban mengenai masalah ini jika paguyuban tidak bisa memecahkan maka sekolah akan melakukan pemanggilan, jika belum bisa diselesaikan ijazah akan ditahan untuk peserta didik Kelas 6 tetapi kegiatan pembelajaran untuk peserta didik tersebut akan tetap berjalan, dan 2) melakukan komunikasi dengan wali murid untuk mengetahui keinginan dan harapan wali murid mengenai sekolah ini, lalu sekolah memberikan informasi, penjelasan serta mengambil jalan tengah untuk mengatasi permasalahan. Sedangkan untuk solusi yang dipilih untuk mengatasi kendala yang berasal dari sekolah yaitu melakukan sosialisasi dengan seluruh warga sekolah dengan sosialisasi maka informasi serta hubungan baik antara semua warga sekolah, seringnya komunikasi yang terjalin maka informasi yang akan disalurkan sesuai dengan tujuan. Selanjutnya untuk mengatasi sulitnya pembagian waktu maka para Ulul Albab memilih waktu di hari-hari libur agar kegiatan rapat tetap bisa berjalan, kegiatan rapat pun bisa dilakukan di luar sekolah tetapi untuk waktu dan tempat tetap didiskusikan terlebih dahulu.

\section{Faktor Pendukung Strategi Pemasaran Jasa Pendidikan dalam Menarik Minat Masyarakat melalui Program Kelas Khusus}

Setiap kegiatan selain terdapat faktor kendala tentunya terdapat faktor pendukung, faktor pendukung ini merupakan faktor-faktor yang diunggulkan dari sekolah ini. Faktor pendukung strategi pemasaran ini yaitu: 1) sarana dan prasarana yang dimiliki oleh kelas khusus ini sudah sangat mencukupi dan baik untuk menunjang kegiatan pembelajaran, 2) model pembelajaran yang dilakukan oleh guru di dalam kelas juga sangat beragam, 3) guru-guru yang mengajar kelas khusus ini memiliki etos serta semangat kerja yang tinggi dan yang terpenting selalu mau belajar, 4) dukungan wali murid melalui paguyuban masing-masing untuk mendukung kegiatan sekolah sangat bagus, dan 5) kemampuan diri sendiri untuk meyakinkan masyarakat sehingga muncul kepercayaan masyarakat terhadap sekolah.

\section{Upaya Mengoptimalkan Faktor Pendukung Strategi Pemasaran Jasa Pendidikan dalam Menarik Minat Masyarakat melalui Program Kelas Khusus}

Faktor pendukung strategi pemasaran jasa pendidikan dalam menarik minat masyarakat melalui program kelas khusus yang dilakukan oleh MI Al-Irsyad Al-Islamiyyah Kota Kediri tentunya memerlukan pengoptimalan secara maksimal. Upaya yang dilakukan untuk mengoptimalkan faktor pendukung yaitu: 1) koordinasi untuk melakukan pembenahan pada kegiatan yang kurang maksimal serta mengadakan pelatihan maupun supervisi untuk memperbaiki serta menambah informasi agar lebih baik lagi dari sebelumnya, 2) menjalin hubungan yang baik antara sekolah dan masyarakat, dan 3) Update data mengenai sekolah-sekolah lain untuk mengumpulkan informasi dan referensi baru yang dapat diterapkan di sekolah agar dapat berkembang lebih baik. 
Berikut ini bagan temuan keseluruhan penelitian mengenai Strategi Pemasaran Jasa Pendidikan dalam Menarik Minat Masyarakat melalui Program Kelas Khusus, tergambarkan pada Gambar 1.

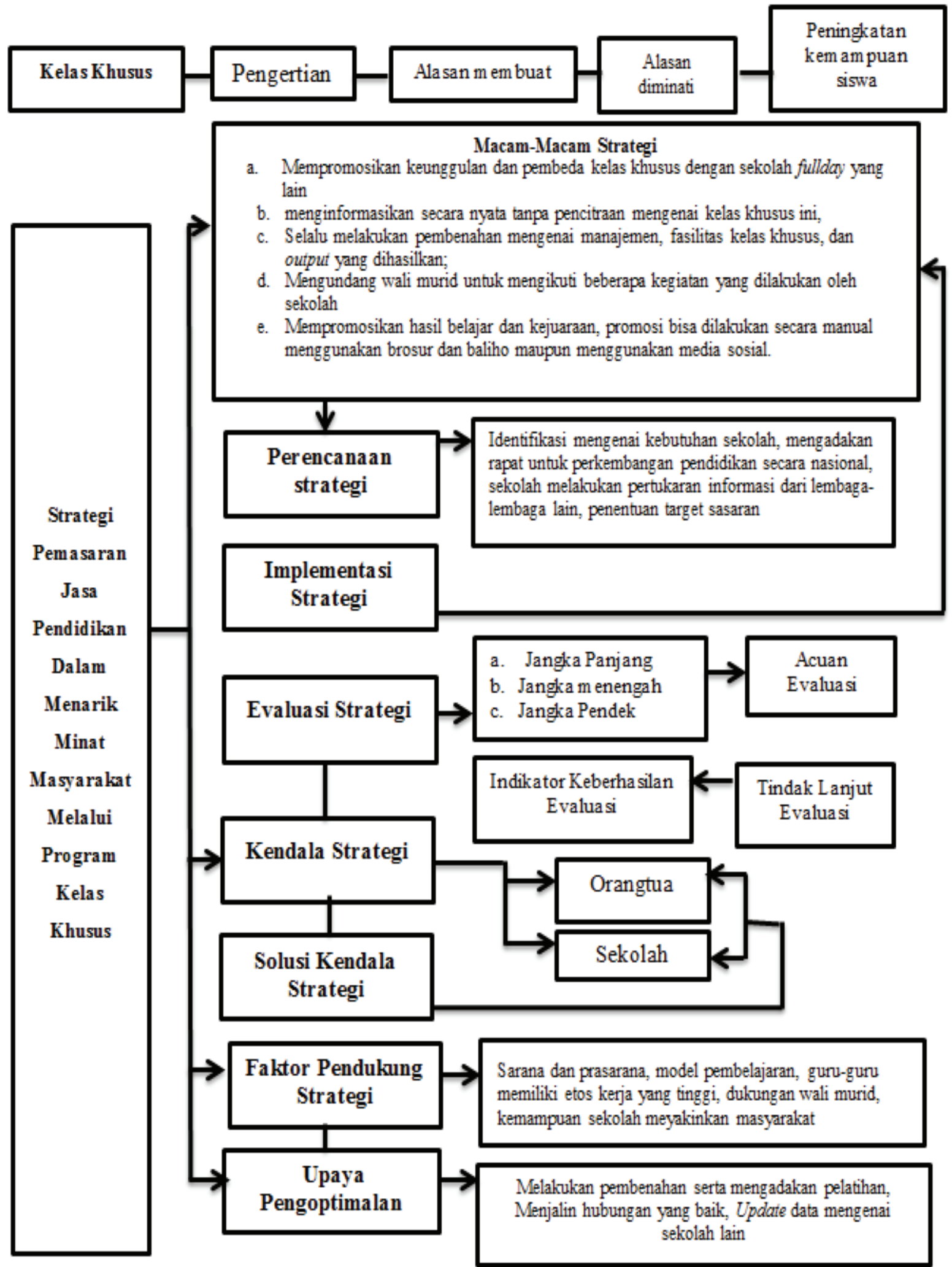

Gambar 1 Bagan Temuan Keseluruhan Strategi Pemasaran Jasa Pendidikan dalam Menarik Minat Masyarakat melalui Program Kelas Khusus yang Dilakukan MI Al-Irsyad Al-Islamiyyah Kota Kediri 


\section{PEMBAHASAN}

\section{Program Kelas Khusus}

Kelas khusus merupakan kelas yang dibuat khusus tentunya juga berbeda dari kelas reguler mengenai penggunaan kurikulum tambahan yang mencerminkan keunggulan madrasah. Keunggulan madrasah disini yaitu mengenai pembelajaran Al-Quran yang sudah menjadi ciri khusus yang ditonjolkan oleh sekolah ini. Alasan dari sekolah membuat kelas khusus ini ialah 1) untuk mengumpulkan anak-anak yang memiliki prestasi tetapi tidak mengecilkan perasaan kelas reguler, 2) dapat membantu pembiayaan sekolah seperti dalam hal gaji dewan guru dan sarpras maupun perawatannya yang ada di kelas khusus, 3) membuat program sekolah ditambah dengan bimbingan belajar serta mengaji sehingga mempermudah orangtua karena tidak perlu mencarikan hal tersebut, dan 4) mengikuti perkembangan zaman, karena zaman sudah semakin maju dan diperlukannya inovasi-inovasi dalam pendidikan. Hal ini sesuai dengan pendapat dari Hadi (2015:33) tentang tujuan dibentuknya kelas khusus ini yang menjelaskan bahwa kelas khusus ini dapat menghasilkan sumber daya manusia berkualitas, kualitas pendidikan dapat berkembang dan ditingkatkan, tenaga pendidikan yang mengajar pada program ini kemampuan dan pengetahuannya dapat meningkat, sekolah dapat meningkatkan potensi yang dimiliki, dan terciptanya keunggulan yang dimiliki oleh sekolah sehingga dapat menghadapi persaingan dalam dunia pendidikan yang semakin meningkat.

Peningkatan kemampuan peserta didik setelah memasuki kelas khusus ini dikarenakan kegiatankegiatan yang diterapkan di kelas khusus, salah satu penerapan kelas khusus ini menurut Charolin (2015:3-4) ialah terdapat penunjang yang ada dalam kelas khusus yaitu tambahan jam belajar. Hal tersebut sesuai dengan hasil penelitian yang mengemukakan bahwa setelah masuk ke kelas khusus ini, peningkatan kemampuan yang dimiliki peserta didik yaitu 1) adanya tambahan pelajaran yang diberikan kepada peserta didik sehingga mereka dibentuk untuk menjadi pribadi yang lebih kuat, jiwa kompetisi peserta didik lebih meningkat, dibuktikannya dengan terus berlomba-lomba untuk mendapatkan peringkat saat di kelas khusus, jadi tidak hanya beberapa anak saja yang menonjol tetapi hampir semua bersaing dalam hal tersebut, 2) peserta didik yang masuk ke kelas khusus ini merupakan peserta didik pilihan, jadi dengan lingkungan yang tingkat keseriusan belajar yang tinggi dapat memberikan dampak yang positif ke sesama, dan 3) waktu dan perhatian yang diberikan lebih banyak diberikan oleh guru kepada peserta didik sehingga memudahkan untuk mengontrol peserta didik;

\section{Strategi Pemasaran Jasa Pendidikan dalam Menarik Minat Masyarakat melalui Program Kelas Khusus}

Beberapa strategi yang digunakan MI Al-Irsyad Al-Islamiyyah Kota Kediri dalam pemasaran jasa pendidikan dalam menarik minat masyarakat pada program kelas khusus ini ialah 1) mempromosikan kelas khusus kepada wali murid serta menjelaskan keunggulan-keunggulan kelas khusus yang menjadi pembeda kelas khusus dengan sekolah fullday yang lain, promosi yang dilakukan oleh sekolah ini melalui media cetak, elektronik, maupun mulut ke mulut yang dilakukan oleh masyarakat. Keunggulan kelas khusus disini selain memperhatikan akademik, perihal istirahat dan makan untuk siswa juga diperhatikan, dijelaskan Tabel 1 ;2) menginformasikan secara nyata tanpa pencitraan mengenai kelas khusus ini, jadi wali murid atau masyarakat dapat melihat langsung secara nyata bagaimana program kelas khusus ini tanpa dibuat-buat. Wali murid dan sekolah selalu melakukan komunikasi untuk pertukaran informasi yang ada di sekolah maupun saran-saran dari wali murid, komunikasi bisa dilakukan secara langsung maupun melalui group whatsapp yang dimiliki; 3) selalu melakukan pembenahan mengenai manajemen, fasilitas kelas khusus, dan output yang dihasilkan. Pembenahan harus selalu dilakukan agar hasil yang dilakukan dapat terus mengalami peningkatan, begitu juga kegiatan yang dilakukan oleh sekolah pada program kelas khusus ini harus di seuaikan dengan keadaan dan zaman; 4) mengundang wali murid untuk mengikuti beberapa kegiatan yang dilakukan oleh sekolah. Melibatkan wali murid dalam kegiatan yang dilakukan oleh sekolah ini memberikan dampak yang baik agar hubungan baik antara kedua belah pihak terjalin lebih baik lagi, sehingga mempermudah penyampaian informasi dan komunikasi; dan 5) mempromosikan hasil-hasil yang diperoleh oleh kelas khusus bisa berupa 
kejuaraan dan hasil-hasil belajar lainnya bisa dalam bidang akademik maupun non akademik, promosi bisa dilakukan secara manual menggunakan brosur dan baliho maupun menggunakan media sosial. Hasil belajar maupun kegiatan yang dilakukan oleh peserta didik maupun sekolah dipromosikan agar masyarakat lebih mengetahui informasi mengenai sekolah. Hal ini sesuai dengan pendapat dari Kirom, dkk (2016) mengenai faktor yang dapat mempengaruhi daya tarik masyarakat yaitu: faktor budaya merupakan suatu kebiasaan yang berkembang dan menjadi kebiasaan di sejumlah masyarakat, keunikan yaitu suatu ciri khusus yang dimiliki oleh suatu organisasi dan tidak dimiliki oleh organisasi lainnya, promosi yaitu kegiatan memasarkan suatu produk ke masyarakat secara luas, keramahtamahan yaitu bagaimana cara menerima masyarakat dengan baik dan sopan, dan kualitas layanan yaitu bagaimana keadaan suatu organisasi dalam melayani masyarakat. Hal ini juga didukung oleh pendapat Newman dan Jahdi (2009:7-9) mengatakan bahwa layanan yang diberikan tidak seperti produk yang bisa disentuh, maka dari itu layanan ini lebih beresiko karena sulit meyakinkan seseorang sebelum mengetahui secara langsung. Maka dari itu, hal yang dilakukan untuk peningkatan layanan ini adalah menawarkan contohcontoh nyata layanan yang dilakukan.

\section{Perencanaan Strategi Pemasaran Jasa Pendidikan dalam Menarik Minat Masyarakat melalui Program Kelas Khusus}

Hasil penelitian menyebutkan bahwa tahapan perencanaan dalam penyusunan strategi yang dipilih sekolah ialah melakukan identifikasi mengenai kebutuhan sekolah. Selanjutnya sekolah biasa mengadakan rapat untuk membahas mengenai perkembangan pendidikan secara nasional lalu mengidentifikasi perkembangan itu agar bisa diterapkan sesuai dengan keadaan sekolah. Selain itu, sekolah melakukan pertukaran informasi dari lembaga-lembaga lain untuk mendapatkan ilmu maupun informasi mengenai lembaga tersebut, lalu sekolah dapat melakukan inovasi terbaru dengan mendapatkan ilmu dari pihakpihak lain tetapi tetap disesuaikan dengan keadaan sekolah. Pada tahap perencanaan ini sekolah juga melakukan penentuan target sasaran yang digunakan untuk pemasaran jasa pendidikan pada kelas khusus ini. Target sasaran untuk strategi pemasaran ini, sasaran yang dipilih sekolah pada kelas khusus ini yaitu peserta didik yang memperoleh peringkat 1-10, tetapi tidak semuanya berkenan dikarenakan di kelas khusus selain akademik peserta didik financial orangtua harus mendukung, target yang kedua ini yaitu berdasarkan peminatan, untuk siswa pindahan jika pindahan tidak dimulai dari Kelas 2 maka diminimkan untuk bisa masuk ke kelas khusus. Murgatroyd dalam Benty dan Gunawan (2015:31) yang menyebutkan bahwa strategi pemasaran yang terbuka luas (broad open strategy) yaitu strategi yang digunakan oleh sekolah tidak membedakan dengan sekolah competitor (saingan), hanya saja sekolah menjalankan pendidikan maupun pembelajaran yang lebih baik. Maka dari itu, pasar sasarannya adalah siswa dalam satu wilayah.

\section{Implementasi Strategi Pemasaran Jasa Pendidikan dalam Menarik Minat Masyarakat melalui Program Kelas Khusus}

Kegiatan implementasi ini merupakan kegiatan penerapan strategi pemasaran jasa pendidikan pada program kelas khusus yang dilakukan oleh sekolah. penerapan strategi yang dilakukan sekolah meliputi 1) sekolah mengikuti lomba-lomba yang diadakan oleh pihak luar untuk digunakan sebagai promosi dan jika memperoleh juara maka nama sekolah dan prestasi sekolah akan lebih dikenal oleh masyarakat secara luas, 2) hasil-hasil belajar siswa, seperti tryout ditempel agar bisa dilihat oleh wali murid atau masyarakat yang ingin masuk ke sekolah tersebut, 3) melakukan pembenahan dalam kegiatan yang kurang optimal pada tahun sebelumnya, seperti contohnya perawatan atau perbaikan sarana dan prasarana yang ada di sekolah; 4) melakukan promosi melalui brosur dan media sosial yang dimiliki oleh sekolah agar masyarakat mudah untuk melihat kegiatan-kegiatan yang dilakukan oleh sekolah serta mencari informasi, 5) sering melakukan sosialisasi dan diskusi dengan walimurid agar tidak terjadi selisih paham dan hubungan baik anatara sekolah dan walimurid tetap terjalin dengan baik. Trimo (2018:15) mengungkapkan bahwa kegiatan dalam pelaksanaan pemasaran jasa pendidikan dapat dilakukan dengan beberapa cara yaitu 1) produk yang dihasilkan dapat berkembang, 2) strategi biaya pendidikan ditentukan secara kompetitif, 3) sekolah dapat memaksimalkan keunggulannya, 4) kegiatan promosi dilakukan secara efektif dan efisien, 5) sumber daya manusia yang ada lebih ditingkatkan kualitasnya, 6) bukti keberhasilan ditunjukan secara nyata, dan 7) kepuasan pelanggan dalam proses layanan yang bermutu. 
Pelaksanaan strategi yang digunakan dalam kegiatan pemasaran dapat menggunakan berbagai jenis pemasaran yang digunakan. Jenis pemasaran jasa pendidikan menurut Benty dan Gunawan (2015) terdapat dua jenis yaitu: 1) melalui media cetak yang meliputi: majalah, surat kabar, iklan, buletin, sticker dan kalender, poster, papan pengumuman dan reklame, pamflet, brosur, leaflet, siaran pers, booklet, spanduk, baliho, dan banner. Selanjutnya 2) melalui media elektronik yang meliputi: televisi, radio, dan pers. Penggunaan media sosial dalam kegiatan pemasaran pendidikan menurut Constantinides and Stagno (2011:19) berpendapat bahwa pemasaran media sosial ini merupakan tempat yang relatif baru, penggunaan pemasaran ini semakin meningkatan ketertarikan perhatian dari suatu kegiatan yang diselenggarakan oleh suatu institusi. Selain jenis yang ada di atas, terdapat pula beberapa strategi promosi terbaik menurut Ekwulugo and Binsardi (2003:321) yaitu melibatkan lulusan, teman-teman, dan saudara dalam kegiatan promosi. Kegiatan promosi secara mulut ke mulut inilah yang mudah dan memberikan manfaat yang baik pula jika pandangan masyarakat mengenai sekolah juga baik. Berdasarkan paparan di atas jenis pemasaran yang digunakan sesuai dengan hasil penelitian. Penjelasan mengenai pelaksanaan strategi yang dilakukan oleh sekolah menggunakan 3 jenis pemasaran yang diguakan dalam menarik minat masyarakat pada kelas khusus ini yaitu sebagai berikut 1) melalui media cetak yaitu dengan brosur, surat pengumuman dan edaran kelas khusus; 2) melalui media elektronik yang dimiliki oleh sekolah yaitu website sekolah, akun Instagram, akun Facebook, channel Youtube, serta whatsapp. Media sosial ini digunakan untuk mengunggah informasi maupun kegiatan yang dilakukan oleh sekolah; dan 3) face to face yang dilakukan dengan cara mengadakan sosialisasi maupun diskusi dengan wali murid dan masyarakat,

\section{Evaluasi Strategi Pemasaran Jasa Pendidikan dalam Menarik Minat Masyarakat melalui Program Kelas Khusus}

Kegiatan evaluasi yang dilakukan sekolah ini dibagi menjadi 3 jenis yaitu evaluasi jangka panjang, jangka menengah, dan jangka pendek. Evaluasi jangka pendek ini dilakukan sebelum masuk ke kelas khusus atau pada peserta didik Kelas 1 dikarenakan pada waktu ini sering dilakukannya evaluasi antara kepala lembaga dengan kepala bagian kelas khusus, selain itu evaluasi ini dilakukan jika diperlukan dan ada hal-hal yang mendadak. Evaluasi jangka menengah yang dilakukan per semester untuk mengidentifikasi hal-hal yang perlu diperbaiki selama semester yang lalu. Sedangkan untuk evaluasi jangka panjang yaitu dilakukan setiap tahunnya untuk membahas kegiatan-kegiatan yang telah berjalan selama setahun, untuk jangka panjang ini tidak dilakukan selama lima tahun sekali dikarenakan seringkali dalam dunia pendidikan mengalami perubahan-perubahan jadi sekolah menerapkan evaluasi jangka panjang dilakukan setiap tahunnya. Hal ini sesuai dengan pendapat dari Rohmitriasih dan Soetopo (2015:404) kegiatan evaluasi mengenai implementasi pemasaran jasa pendidikan dilakukan setiap bulan sekali serta dilakukan secara rutin pada pertemuan antara kepala sekolah dengan wakil kepala sekolah maupun guru, selain itu terdapat pula evaluasi yang dilakukan setiap tahun untuk kegiatan publikasi. Berdasarkan kedua hal tersebut maka dapat diketahui bahwa evaluasi dapat dilakukan dengan jangka panjang, pendek, maupun menengah dengan kurun waktu minggu, bulan dan tahun.

Kegiatan selanjutnya setelah melakukan evaluasi kegiatan yang dilakukan oleh sekolah adalah melakukan rapat dengan seluruh warga sekolah yang berkaitan dengan kelas khusus, melakukan identifikasi mengenai skala prioritas, dan menerapkan hasil hasil evaluasi dengan kesepakatan rapat. Setelah melakukan kegiatan evaluasi dapat diketahui bahwa indikator keberhasilan pemasaran jasa pendidikan dalam menarik minat masyarakat melalui kelas khusus ini adalah keberhasilan sekolah untuk meningkatkan daya tarik masyarakat dalam program kelas khusus, terbukti dari meningkatnya jumlah peserta didik yang setiap tahun mengalami peningkatan dan untuk tahun ini bisa sampai overload. Hal ini sesuai dengan pendapat dari Muzzarol (1998:172) mengemukakan bahwa faktor penentu keberhasilan yaitu Image and resources (pandangan dan kualitas sumber daya), faktor ini mengukur tingkat kepercayaan dan pandangan masyarakat terhadap sumber daya yang dimiliki oleh institusi pendidikan. Seperti kualitas lulusan, banyaknya ekstrakurikuler dan kualitas fasilitas yang dimiliki oleh sekolah. Ketika masyarakat percaya dan memiliki gambaran mengenai sekolah secara baik maka daya tarik masyarakat terhadap sekolah dapat meningkat terbukti dari keinginan peserta didik yang sangat tinggi untuk masuk ke kelas khusus ini. 


\section{Faktor Kendala Strategi Pemasaran Jasa Pendidikan dalam Menarik Minat Masyarakat melalui Program Kelas Khusus}

Hasil penelitian yang ditemukan mengenai faktor kendala strategi pemasaran jasa pendidikan dalam menarik minat masyarakat melalui program kelas khusus, ditemukan bahwa kendala yang dialami berasal dari wali murid dan dari sekolah. Naude and Ivy (1999:134) mengemukakan bahwa jika di dalam kegiatan terjadi kendala antara kebutuhan siswa dengan tujuan pendidikan, tujuan pendidikanlah yang harus dijadikan pertimbangan utama. Kendala yang berasal dari wali murid ialah 1) wali murid yang memiliki ekspektasi yang tinggi, ditakutkan ekspektasi mereka tidak sesuai dengan apa yang diterapkan. Maka dari itu kendala muncul ketika keinginan wali murid dan sekolah mengalami perbedaan; dan 2) terdapat beberapa wali murid yang kurang memiliki komitmen, komitmen disini menyangkut masalah pembayaran karena di kelas khusus ini sedikit lebih banyak biaya dari pada kelas reguler. Jika pembiayaan mereka rendah tetapi tetap memaksakan untuk masuk maka akan mengganggu kelancaran program-program yang ada. Sedangkan kendala-kendala yang dialami berasal dari pihak sekolah sebagai berikut: 1) tidak semua guru yang dapat menjelaskan dan paham mengenai kelas khusus sehingga mengakibatkan perbedaan pemahaman, jadi ketika wali murid menanyakan ditakutkan berbeda penjelasan; dan 2) kesibukan masing-masing Ulul Albab sekolah sehingga sulit sekali mencari waktu yang tepat untuk melakukan pertemuan berdiskusi. Kedua kendala di atas sesuai dengan pendapat dari Rohmitriasih dan Soetopo (2015:406) menyebutkan bahwa masyarakat yang masih sering meremehkan akan pentingnya pendidikan, dan tenaga pendidik maupun kependidikan yang ada di sekolah kurang dapat menyampaikan dengan baik mengenai hal-hal yang ada di sekolah sehingga tidak semua tersampaikan di masyarakat. Sedangkan menurut Kustian,dkk (2018: 96) faktor penghambat strategi pemasaran jasa pendidikan dikarenakan dalam strategi pemasaran belum ada tenaga ahli yang menangani. Problema pemasaran jasa pendidikan menurut Rohmitriasih dan Soetopo (2015:406) mengungkapkan bahwa ketidaksesuaian kebutuhan masyarakat terhadap pendidikan yang dilakukan oleh sekolah.

\section{Solusi Yang Dilakukan untuk Mengatasi Kendala yang Dihadapi Strategi Pemasaran Jasa Pendidikan dalam Menarik Minat Masyarakat melalui Program Kelas Khusus}

Kendala yang dihadapi berasal dari faktor orangtua dan sekolah, maka solusi yang digunakan juga digunakan untuk orangtua dan sekolah. solusi yang dipilih untuk mengatasi kendala yang berasal dari sekolah yaitu melakukan sosialisasi dengan seluruh warga sekolah dengan sosialisasi maka informasi serta hubungan baik antara semua warga sekolah, seringnya komunikasi yang terjalin maka informasi yang akan disalurkan sesuai dengan tujuan. Selanjutnya untuk mengatasi sulitnya pembagian waktu maka para Ulul Albab memilih waktu di hari-hari libur agar kegiatan rapat tetap bisa berjalan, kegiatan rapat pun bisa dilakukan di luar sekolah tetapi untuk waktu dan tempat tetap didiskusikan terlebih dahulu.

Sedangkan solusi yang dipilih untuk mengatasi kendala yang berasal dari orangtua yaitu: 1) Untuk mengatasi masalah pembiayaan, yang pertama dilakukan dengan komunikasi dan solusi dengan paguyuban mengenai masalah ini jika paguyuban tidak bisa memecahkan maka sekolah akan melakukan pemanggilan, jika belum bisa diselesaikan ijazah akan ditahan untuk peserta didik Kelas 6 tetapi kegiatan pembelajaran untuk peserta didik tersebut akan tetap berjalan; dan 2) melakukan komunikasi dengan wali murid untuk mengetahui keinginan dan harapan wali murid mengenai sekolah ini, lalu sekolah memberikan informasi, penjelasan serta mengambil jalan tengah untuk mengatasi permasalahan. Hal ini sesuai dengan pendapat dari Slameto dan Kriswandani dalam Benty dan Gunawan (2015:81) mengenai upaya mempengaruhi masyarakat yaitu sebagai berikut: 1) memberikan penjelasan kepada masyarakat bahwa jika masyarakat mau ikut serta dalam kebijakan maka akan menguntungkan masyarakat tersebut, 2) kegiatan yang diselenggarakan harus selalu mengikut sertakan masyarakat didalamnya, 3) mengikutsertakan masyarakat yang mempunyai citra baik dan tokoh-tokoh penting diikut sertakan agar masyarakat yang mencontoh mereka juga mengimplementasikan kebijakan tersebut, 4) meyakinkan masyarakat bahwa kepentingan mereka dapat dilayani dengan baik jika mereka mau ikut dalam partisipasi dalam aturan-aturan yang dibuat. Maka dari itu, pembuatan kebijakan harus berhubungan dengan apa yang dibutuhkan oleh masyarakat, dan 5) mewujudkan aspirasi masyarakat dengan cara menyadarkan bahwa masyarakat untuk ikut berpartisipasi dari pembuatan kebijakan yang ditetapkan. 


\section{Faktor Pendukung Strategi Pemasaran Jasa Pendidikan dalam Menarik Minat Masyarakat melalui Program Kelas Khusus}

Setiap kegiatan selain terdapat faktor kendala tentunya terdapat faktor pendukung, faktor pendukung ini merupakan faktor-faktor yang diunggulkan dari sekolah ini. Faktor pendukung strategi pemasaran ini yaitu: 1) sarana dan prasarana yang dimiliki oleh kelas khusus ini sudah sangat mencukupi dan baik untuk menunjang kegiatan pembelajaran, 2) model pembelajaran yang dilakukan oleh guru di dalam kelas juga sangat beragam, 3) guru-guru yang mengajar kelas khusus ini memiliki etos serta semangat kerja yang tinggi dan yang terpenting selalu mau belajar, 4) dukungan wali murid melalui paguyuban masing-masing untuk mendukung kegiatan sekolah sangat bagus, dan 5) kemampuan diri sendiri untuk meyakinkan masyarakat sehingga muncul kepercayaan masyarakat terhadap sekolah. Hal ini sesuai dengan pendapat mengenai faktor pendukung strategi pemasaran jasa pendidikan menurut Kustian, dkk (2018:96) terdapat beberapa faktor yaitu 1) sekolah memiliki letak yang strategis berada di tengah kota, dijangkau oleh transportasi umum maupun pribadi, terletak pada sisi jalan raya, serta instansi pemerintahan yang letaknya dengan sekolah, 2) sekolah berada pada naungan langsung yayasan, 3) masyarakat sangat mempercayai sekolah begitu tinggi, 4) semua kalangan dapat menjangkau biaya sekolah, 5) kegiatan ekstrakurikuler yang sangat beragam, dan 6) berkualitasnya tenaga pendidik yang ada di sekolah.

\section{Upaya Mengoptimalkan Faktor Pendukung Strategi Pemasaran Jasa Pendidikan dalam Menarik Minat Masyarakat melalui Program Kelas Khusus}

Pengoptimalan faktor pendukung salah satunya memperhatiakan wali murid. Harapan wali murid mengenai kelas khusus ini yaitu: 1) misi yang ada di sekolah berakhlakul karimah diterapkan dengan baik; 2) wali murid menginginkan selain mengajarkan materi yang baru, para guru juga harus sering melakukan review untuk materi yang telah diajarkan agar peserta didik tetap ingat mengenai materimateri tersebut untuk keperluan mengikuti lomba olimpiade maupun untuk persiapan di kelas atas, dan 3) wali murid menginginkan kelas khusus ini tetap ada, kelas khusus ini mengarahkan peserta didik dalam menentukan prinsipnya dengan kegiatan-kegiatan yang dilakukan sekolah. Hal ini sesuai dengan tujuan dari tujuan dari pemasaran jasa pendidikan menurut Faizin (2017) yaitu: 1) masyarakat mendapat informasi dari produk-produk lembaga pendidikan, 2) masyarakat dapat tertarik serta meningkatkan minatnya terhadap suatu lembaga pendidikan, 3) pembedaan produk dari lembaga pendidikan satu dengan yang lain, 4) masyarakat memberikan penilaian lebih terhadap produk yang diberikan oleh lembaga pendidikan, dan 5) eksistensi lembaga pendidikan di mata masyarakat tetap stabil.

\section{SIMPULAN}

Kelas khusus merupakan program unggulan yang dimiliki oleh sekolah. Tujuan sekolah membuat kelas khusus untuk meningkatan kemampuan peserta didik dalam mengikuti perkembangan zaman mengenai kebutuhan yang diperlukan oleh masyarakat untuk saat ini. Keunggulan kelas khusus dilakukan dengan memberikan fasilitas dan layanan pembelajaran yang lebih intensif dari kelas-kelas reguler, antara lain layanan tambahan pembelajaran keagamaan dan kegiatan sekolah yang bercirikan agama. Strategi pemasaran jasa pendidikan dalam menarik minat masyarakat melalui program kelas khusus dapat dilakukan dengan melakukan promosi, menjalin hubungan baik dengan masyarakat, dan selalu melakukan pembenahan terhadap kegiatan dinilai kurang maksimal. Perencanaan strategi dilakukan dengan identifikasi kebutuhan sekolah, pembahasan perkembangan pendidikan secara nasional, pertukaran informasi dengan lembaga lain, dan penentuan sasaran yang akan dicapai. Implementasi strategi pemasaran yang dilakukan dengan cara yang beragam, antara lain mengikuti berbagai macam perlombaan sebagai promosi, hasil belajar siswa dipamerkan, pembenahan kegiatan secara intensif, melakukan promosi melalui media cetak dan media elektronik, melakukan sosialisasi dan diskusi dengan wali murid. Kegiatan evaluasi strategi pemasaran yang dilakukan secara jangka panjang, jangka menengah, dan jangka pendek dengan cara mengidentifikasi kegiatan sebelumnya dan memperhatikan minat orangtua terhadap kegiatan sekolah. 
Strategi pemasaran jasa pendidikan mendapat hambatan dari wali murid yang memiliki ekspektasi tinggi terhadap sekolah dan terdapat wali murid yang kurang memiliki komitmen. Hambatan lainnya dapat berasal dari sekolah yaitu tidak semua guru memahami misi yang sama mengenai kelas khusus sehingga membuat mereka kesulitan untuk menyampaikan informasi kepada wali murid dan masyarakat.

\section{REFERENCE}

Benty, D. D. N. dan Gunawan, I. 2015. Manajemen Hubungan Sekolah dan Masyarakat. Malang: Penerbit UM Press.

Charolin, S. 2015. Implementasi Program Kelas Khusus Studi Kasus di SMA Negeri 1 Nganjuk. Jurnal Inspirasi Manajemen Pendidikan, 2(2). Dari https://jurnalmahasiswa.unesa.ac.id/index.php/inspirasi-manajemenpendidikan/article/view/14630. Diakses Tanggal 7 Januari 2020

Constantinides, E and Stagno, M. 2011. Potential Of The Social Media As Instruments Of Higher Education Marketing: A Segmentation Study. Jurnal Of Marketing For Higher Education. 21(1), 7-24. Dari https:// www.tandfonline.com/doi/abs/ 10.1080/03098770802638226. Diakses Tanggal 3 Juli 2020

Ekwulugo, F dan Binsardi,A. 2003. International Marketing Of British Education: Research On The Students Perception and the UK Market Penetration. Marketing intelligence and planning. 21(5), 318-327) Dari https://www.emerald.com/ insight /content/ doi/10.1108/02634500310490265/full/html. Diakses Tanggal 28 Juni 2020

Faizin, I. 2017. Strategi Pemasaran Jasa Pendidikan dalam Meningkatkan Nilai Jual Madrasah. Jurnal Madaniyah, 7(2). Dari https://media.neliti. com/media/publications/195108-ID-strategi-pemasaran-jasa-pendidikandalam.pdf. Diakses Tanggal 12 Maret 2019

Hadi, Y. 2015. Pengelolaan Kelas Unggulan Dalam Meningkatkan Prestasi Belajar Siswa Pada Pendidikan Mata Pelajaran Pendidikan Agama Islam di SMAN 1 Marabahan Kabupaten Barito Kuala. (Online). (http:// etheses.uin-malang.ac.id/5223/1/11110216.pdf). Diakses Tanggal 7 Januari 2020.

Kirom, N.R., Sudarmiatin, dan Putra, I.W.J.A. 2016. Faktor-Faktor Penentu Daya Tarik Wisata Budaya dan Pengaruhnya terhadap Kepuasan Wisatawan. Jurnal Pendidikan: Teori, Penelitian, dan Pengembangan, 1(3), 536-546. Dari journal.um.ac.id/index.php/jptpp/article/view/6184. Diakses Tanggal 23 Maret 2019

Kustian,dkk. 2018. Strategi Pemasaran Jasa Pendidikan Dalam Meningkatkan Kuantitas Siswa.Tadbir Muwahhid, 2(2), 87-97. Dari https://ojs.unida.ac.id/JTM/article /view/1176/pdf. Diakses tanggal 14 Mei 2020

Muzzarol, T. 1998. Critical Success Factors For International Education Marketing. International Jurnal Of Educational Management, 12(4),163-175. Dari https:/www.emerald.com/insight/content/doi/10.1108/09513 549810 220623/full/html. Diakses Tanggal 28 Juni 2020

Naude, P and Ivy,J. 1999. The Marketing Strategies of Universities In The United Kingdom. The International Journal Of Educational Management. 13(3), 126-134. Dari https:// www.emerald.com/insight/content/doi/10.1108/ 09513549910269485/full/html. Diakses Tanggal 28 Juni 2020

Newman, S and Jahdi, K. 2009. Marketisation Of Education: Marketing, Rhetoric, and Reality. Journal Of Further And Higher Education, 33(1), 1-11. Dari https://www.emerald.com/insight/content/ doi/10.1108/09513540810875635/full/html?mobileUi $=0 \&$ fullSc $=1 \& \mathrm{mbSc}=1 \&$ fullSc$=1 \&$ full $\mathrm{Sc}=1 \&$ full $\mathrm{Sc}=1$. Diakses Tanggal 3 Juli 2020

Rohmitriasih dan Soetopo, H. 2015.Strategi Pemasaran Jasa Pendidikan dalam Meningkatkan Loyalitas Pelanggan. Jurnal Manajemen Pendidikan, 24(5), 402-407. Dari http://ap.fip.um.ac.id/wp-content/uploads/2015/05/ volume-24-no.-550-55.pdf. Diakses Tanggal 5 Mei 2019

Trimo. 2018. Manajemen Pemasaran Jasa Pendidikan di SMK Bhineka Karya Surakarta. Dari http://eprints.ums. ac.id /60259/16/NASKAH\% 20PUBLIKASI.pdf. Diakses Tanggal 12 Maret 2019

Ulfatin, N. 2015. Metode Penelitian Kualitatif di Bidang Pendidikan: Teori dan Aplikasinya. Malang: Bayumedia Publishing.

Yin, R.K. 2009. Case Study Research: Design and Methods. (Online). Dari https://books.google.co.id/books?id=. Diakses Tanggal 04 Juli 2020 